\title{
A magyar nyelv és irodalom barátainak, tanárainak lapja
}

\author{
Blankó Miklós \\ Eötvös Loránd Tudományegyetem Bölcsészettudományi Kar, hallgató \\ Magyar Nyelvi Szolgáltató Iroda, irodavezető
}

\begin{abstract}
Absztrakt
A Magyartanítás című emblematikus folyóirat megüresedett helyét 2019-től a Magyaróra vette át. A folyóirat ugyan a Magyartanítás folyóirat szellemi örökségére épít, mégis sok tekintetben megújult. 2019 őszén a Bánk bán-búvárlatok, 2020 tavaszán pedig a Retorika minden tárgyban címü folyóiratszám jelent meg. Esettanulmányomban a szerkesztőség eddigi tapasztalatait felhasználva ismertetem a Magyarórát, és a jövőképet felvázolva kiemelem pár későbbi lapszám tervét is.
\end{abstract}

Kulcsszavak: magyaróra, irodalomtanítás, anyanyelv-pedagógia, szakmódszertan, folyóirat

\section{Bevezetés}

A magyar nyelv és irodalom barátainak, tanárainak lapja - ezzel az alcímmel indult (remélhetőleg hosszú) útjára a Magyaróra címü folyóirat 2019 őszén. Már az eddig megjelent két összevont szám (Bánk bán-búvárlatok, Retorika minden tárgyban) is sok új tapasztalatot adott a szerkesztőség számára. Esettanulmányomban a szerkesztőség szemszögéből mutatom be a már megjelent két számot, valamint felvázolom a mára már megfogalmazott jövőbeli terveket is.

\section{Az első gondolattól a címadásig}

A Magyaróra megszületésének első eseménye 2019 tavaszára tehető, amikor Adamikné Jászó Anna (a Magyartanítás főszerkesztője) felkereste Balázs Gézátazzal, hogy a korábban általa vezetett folyóirat megszűnése-átnevezése után jó lenne tovább vinni a sok évtizedet megélt lap szellemi örökségét. A folyóirat kiadását a tavaly éppen harminc esztendős Anyanyelvápolók Szövetsége vállalta Juhász Judit elnök támogatásával. A felelős szerkesztő Balázs Géza lett, a szerkesztőség további tagjai: Blankó Miklós, Lengyel Klára és Pölcz Ádám. A lap szakmai-tudományos minőségét a szerkesztőbizottság 
névsora is szavatolja: Adamikné Jászó Anna (elnök), Balázs Géza, Baranyai Katalin, Fráter Zoltán, Minya Károly és Széplaki Erzsébet is elfogadták felkérésünket. Az eredeti terv az volt, hogy a Magyartanítás hagyományaira építve, de azt erősen megújítva Új Magyartanítás néven folytatnánk a folyóiratot, azonban mivel a címadás során jogi akadályba ütköztünk, más címet kellett kitalálnunk. A Magyarórára (Minya Károly ötlete) esett a választásunk. Az elsőre egyszerűnek tűnő cím azért kifejező, mivel jelzi a kétirányúságot: a tanítás és a tanulás, a tanár és a tanuló kettősségét, sőt az alkotó, a közvetítő és a befogadó hármasságát. Az alcímmel (A magyar nyelv és irodalom barátainak, tanárainak lapja) pedig az olvasói közönség körét szerette volna megnyitni a szerkesztőség azok felé, akik nem tanárok, de elkötelezettek a hazai anyanyelvi kultúra mellett.

\section{Bánk bán-búvárlatok}

A folyóirat profiljának kialakításakor hamar a tematikus számok mellett döntöttünk. Katona József Bánk bánja éppen 2019-ben lett 200 éves (a Katona által jóváhagyott végső változat 1819-ben született). A Bánk bán a magyar irodalom egyik legfontosabb alkotása, a középiskolában megkerülhetetlen tananyag, mégis az egyik legnehezebben tanítható olvasmány. A szerkesztőség úgy érezte, hogy a Bánk bán tanításának problematikájával a mủ értelmezési nehézségein túl általánosan is rávilágít arra, hogy melyek lehetnek a nehezebb irodalmi alkotások tanításának 21. századi alternatívái (I. évfolyam 1-4. szám).

A 114 oldalas tematikus számot Adamikné Jászó Anna köszöntője nyitja meg. A „klasszikus” Bánk bán című egység négy tanulmányt, A „modern” Bánk bán címü három tanulmányt és egy interjút, a Bánk bán a magyarórán címü hét tanulmányt, egy körkérdést, egy feladatsort és egy novellát vonultat fel, míg a Bánk bán a magyarórán túl című rész három tanulmányt és egy interjút. A folyóiratszámot a Fórum rovat zárja, amely a témán kívüli kérdésekkel foglalkozik. A 33 szerző többsége magyartanár, irodalmár, nyelvész, de van közöttük történész, énektanár, múzeumigazgató, újságíró, író-dramaturg és több egyetemi hallgató is. A tanárok Budapest mellett Kecskemétről, Bajáról, Pécsről, Székesfehérvárról, Sopronból, Komáromból, Kolozsvárról, Nagyváradról és Kisvárdáról juttatták el írásaikat a szerkesztőséghez.

A szám további bemutatása helyett a Magyar Nemzet-beli esszémből idézek, amelyben a Bánk bán-búvárlatok tapasztalatait gyűjtöttem egybe. „Van olyan tanár, aki projektmódszeren keresztül közelít a szóban forgó dráma felé: a diákok saját »fordítást «, jelmeztervet készíthetnek, de összeállíthatják Tiborc életrajzát, vagy csetre átvihetik Gertrudis és Bánk vitáját. Egy másik tanár, az infokommunikációs eszközöket segítségül hívva, a történetet infografikán ábrázoltatja tanítványaival. Van, aki Endre király lelki világán keresztül dolgozza fel a szöveget. Többen használják az idén megjelent Nádasdy Ádám-féle fordítást, amely valóban csökkenti a különbséget napjaink és a 
keletkezés nyelve között. Más tanárok pedig a szintén ebben az évben másodszorra kiadott, Beke József által összeállított Bánk bán szótárt használják a tanórákon. / A tantárgyi integráció is megjelenik a Magyarórában felvázolt alternatívák között: az erkeli opera és a katonai dráma együttes tanítása remek összevonása az ének- és magyarórai tananyagnak, az operaadaptáció akár dramaturgiai, akár stilisztikai összevetése sem hiszem, hogy érdektelen lenne a mai fiatalok számára. Utat lehet nyitni a történelemóra felé is, amelyen érdekes megvizsgálni, hogyan is történhetett a királynégyilkosság 1213-ban, és vajon mi Katona szerzői szüleménye. / A múzeum- és színházpedagógiai módszerekről sem szabad megfeledkezni, hiszen több kulturális intézmény kínál a témában foglalkozásokat, de magán- a tanórán is el lehet játszatni bizonyos jeleneteket a diákokkal. Aki mindezt kipróbálta, de a tanulói még mindig nem akarják a Bánkot olvasni, az jogosan mondhatja, hogy nem tanítható ma már ez a mü. / A lehetőségek tárháza tehát elég széles a magyartanárok számára is. Csak akarni kell, és hinni abban, hogy van értelme tanítani - a Bánk bánt is." (Blankó, 2019). .

Annál, hogy a szerkesztőség hogyan értékeli a lapot, sokkal fontosabb a számos recenzió szövege, valamint a személyes visszajelzések. A folyóiratszámot 2019. november 22-én a kecskeméti Katona József Emlékházban mutattuk be. 2020. február 21-én, az anyanyelvek napján pedig egy pódiumbeszélgetést tartottunk a Magyaróráról és a Bánk bán-búvárlatokról.

\section{Retorika minden tárgyban}

Koncepciónknak megfelelően a tavaszi duplaszám (II. évfolyam 1-2.) témája a retorikatanítás lett. A retorikatanítás elsőre nem tünik nehéznek, ugyanakkor a klasszikus retorikai alapok mai adaptálása már nem mindig bizonyul olyan egyszerünek az iskolában. A retorikatanítás végig kell, hogy kísérje az egész köznevelési folyamatot, és nem csak az anyanyelvi órákon történik a retorikai képességek elsajátítása. Ezért választottuk az Arisztotelésztől kölcsönzött címet: Retorika minden tárgyban - hívja fel a figyelmet a bevezető tanulmányban Pölcz Ádám. A retorika, a meggyőzés, a szónoklat tudománya áthatja az életünket, éppen ezért van miből példákat, játékos szituációkat meríteniük a tanároknak. A folyóiratszám 162 oldala ebből szemezget.

Az első tematikus egység a Retorika minden tárgyban címet kapta, négy tanulmányt és egy interjút tartalmaz. A Retorika és iskola tizenegy tanulmánynak és egy körkérdésnek ad helyet, míg a „Rétor” diákok az iskolán túl hat tanulmányt és két interjút közöl. A három tematikus részt két, más témájú tanulmány, illetve a Fórum és az Aktuális rovat követi. A 38 szerző döntő része ez esetben is magyartanár, nyelvész, de van közöttük tanító, történelemtanár, angoltanár, neveléstudós, irodalomtörténész, színész, jogász, médiakutató, újságíró és egyetemi hallgató. A szerzők lakhelyei a főváros mellett: Nagyvárad, Szeged, Kézdivásárhely, Nyíregyháza, Héreg, Eger, Berettyóújfalu, Székesfehérvár, Sátoraljaújhely és Luxemburg. 
Ezúttal is a Magyar Nemzet-beli összefoglalómat idézem: „Már csak az a kérdés, hogy hol, hogyan és miért tanítsanak retorikát. / Hol? A retorika tehát - Arisztotelész szavaival élve - ott van minden tárgyban. És mivel enynyire az orrunk előtt hever, időnként el is feledkezünk arról, hogy müveljük, fejlődjünk mi magunk, és fejlesszük a tanulókat benne. Éppen emiatt az ellentmondásos helyzet miatt gondoltuk úgy, hogy a Magyaróra című folyóirat idei tavaszi számának a retorikatanítás legyen a témája. A retorika klasszikus és újszerű tudományos megragadása mellett a hangsúly most is az iskolán volt. A retorikatanítás az iskolai nevelés minden szintjén és (majdnem) minden tantárgyában megjelenik. Szinte végtelen számú tanítási ötletet sorakoztatnak fel a szerzők, és nem feledkeznek meg a hazánkban is nagy múltú szónokversenyekről, amelyeket nemcsak középiskolásoknak, hanem egyetemistáknak is megszerveznek évről évre. / Hogyan? [...] A Magyaróra címü folyóiratban a tanárok a bábjátékos helyzetgyakorlatoktól kezdve a Harry Potterrel és a különböző reklámszövegekkel kapcsolatos retorikai gyakorlatokon át a történelemórai szónoklatokig sokféle kipróbált »receptet« osztanak meg. A legelemibb szinten már az alsó tagozatos fogalmazástanításnál is megjelenik a retorika, ahol a hármas tagolás elvét (bevezetés, tárgyalás, befejezés) tanulják meg a kisiskolások. / Miért? [...] Az élet tele van retorikával, és nem kell ahhoz politikusnak vagy lelkésznek lennünk, hogy a retorika eszközeivel kelljen élnünk, hogy szembetalálkozzunk a megszólalás, a véleménykifejtés és a vita nehézségeivel. A hétköznapokra felkészítő iskola pontosan ezeket az élethelyzeteket ragadja ki - ahogyan szerencsére sok helyütt teszik is -, és nem (csak) ünnepi beszédeket, parlamenti szónoklatokat gyártat a diákokkal, olyan szövegeket, amelyek sem korukhoz és érdeklődésükhöz, sem az élet realitásához nem kapcsolódnak. Hiszen valljuk be, kevesünk mond ünnepi beszédeket vagy parlamenti felszólalásokat, annál többeknek kell viszont, hogy meggyőzzék feletteseiket a saját alkalmasságukról, hogy »eladják « ötleteiket, és megvédjék érdekeiket, hogy képviselni tudják álláspontjukat a családban, a barátoknál, a munkahelyen, a világban. Az élet retorikája ez volna." (Blankó, 2020).

\section{Jövőkép: A késő modernség (1956-1980) magyar irodalmának tanítása; A gyermekirodalom tanítása}

A késő modernség (1956-1980) magyar irodalmának tanítása - ezzel a munkacímmel hirdettük meg a novemberi (II. évfolyam 3-4.) összevont számot. A szerkesztőség várja a forradalom utáni és posztmodernség előtti hazai irodalmi művekre és azok tanítására irányuló írásokat - különös tekintettel a Kerettantervben szereplő tételekre. A szám szerkesztéséhez Fráter Zoltán, a szerkesztőbizottság tagját hívjuk segítségül.

Meg kell említenem egy későbbi tervünket is: a Magyaróra A gyermekirodalom tanítása címü tematikus számát. A tervet azért is érdekesnek tartom, mert a gyermek- és ifjúsági irodalom egyszerre elsődleges eleme az óvodai és 
alsó tagozatos irodalmi nevelésnek, de a felső tagozatban és a középiskolában is megjelenik egy-egy mü erejéig. A „felnőttirodalmak” tanórai értelmezése ezen olvasási és elemzési élmények nélkül elképzelhetetlen. A folyóiratszám éppen ezért a gyermekirodalom tanításával kapcsolatos óvodapedagógusi, tanítói és tanári tapasztalatok összegzését és cseréjét szolgálná.

A Magyaróra szerkesztősége egyszerre szeretné az iskolai magyartanítás „klasszikus” és problematikus kérdéseit vizsgálni, és a tematikus számokkal kis kézikönyvszerű oktatási-módszertani segédletet adni a pedagógusok kezébe (a nem témába vágó írásokkal is színezve). Az irodalom és a nyelv iránt erősen elkötelezetteknek pedig egy-egy tárgykörre vonatkozó átfogó ismeretanyagot adunk. A Magyaróra szép példája lehet annak, hogyan kell a tudomány felől a tudományos ismeretterjesztés igényességével a gyakorlat, az alkalmazott tudomány felé fordulni.

\section{Irodalom}

Blankó, M. (2019). Nemzeti minimum. Kötelező olvasmányok - Iskola Bánkkal vagy Bánk nélkül. Magyar Nemzet, 2019. december 7. https://magyarnemzet.hu/ lugas-rovat/nemzeti-minimum-7549598/

Blankó, M. (2020). Az élet retorikája. Magyar Nemzet, 2020. május 25. https:// magyarnemzet.hu/lugas-rovat/az-elet-retorikaja-8158028/ 


\section{Blankó, $M$.}

\section{Magyaóra, a journal for the friends and teachers of Hungarian language and literature}

The journal Magyaróra has filled the void left by loss of Magyartanitás in 2019. While building on the intellectual heritage of Magyartanitás, the periodical has been reinvigorated in various ways. The autumn of 2019 saw the publication of Bánk bán-búvárlatok, while in the spring of 2020 Retorika minden tárgyban appeared. In this case study, I present Magyaróra based on the the experience of working on the editorial board and highlight some of the journal's future plans.

Keywords: Magyaróra, literature teaching, mother tongue pedagogy, methodology, journal

Blankó Miklós: https://orcid.org/0000-0002-6878-2331 